J. Clin. Chem. Clin. Biochem.

Vol. 19, 1981, pp. 99-107

\title{
Somatostatin Binding Factor from Chicken Pancreas
}

By F. Diel

Department Toxicology, Institute of Occupational Health at Dortmund University, Dortmund, Federal Republic
of Germany

N. Bethge, Elisabeth Schneider and H.-J. Quabbe

Department of Medicine, Section of Endocrinology, Klinikum Steglitz, Free University Berlin

(Received March 10/August 27, 1980)

Summary: A soluble somatostatin binding factor was detected in cell-free extracts from chicken pancreas. For binding measurements $\mathrm{Tyr}^{1}$-somatostatin was radio-labeled with ${ }^{125} \mathrm{I}$ by the lactoperoxidase technique. Specific radioactivity of about $18.5 \mathrm{MBq} / \mathrm{nmol}$ was achieved. Maximal total binding is approximately $0.17\left(\frac{\mathrm{B}}{\mathrm{T}}\right)$ in the presence of $30 \mathrm{mg} / \mathrm{l}$ pancreatic protein. The specific binding is 0.10 and is suppressed by addition of $1 \mathrm{mg} / \mathrm{l}$ synthetic cold cyclic somatostatin.

The dose-response curve of synthetic cyclic somatostatin is in the range of $0.6-600 \mathrm{nmol} / 1 . \mathrm{Ca}^{2+}$ and reduced thiolreagents inhibit the specific binding. Insulin, glucagon and corticotropin show a low, and luliberin and reduced somatostatin a high cross-reactivity. Molecular weight was estimated by gel filtration and the specific binding molecule was eluted at a $\mathrm{K}_{\mathrm{av}}=0.2$ on an Ultrogel ${ }^{\circledR}$ (AcA 54) column. This corresponds to $M_{\mathrm{r}} 40000$. Electrophoretic properties of the binding complex and semipurification by polyacrylamide disc gel electrophoresis: relative mobility of the ${ }^{125} \mathrm{I}$-Tyr-somatostatin binding complex is about 0.6 . Relative mobilities of binding-protein fractions are 0.71 and 0.74. Highest relative specific binding was detected in the $(100000 \mathrm{~g})$ cytosol fractions. Binding with cell-free extracts from the splenic lobe area was 4 fold higher than that from other parts of the chicken pancreas.

\section{Somatostatin-Bindungsfaktor aus Hühnerpankreas}

Zusammenfassung: Ein löslicher Somatostatin-Bindungsfaktor wird in zellfreien Extrakten von Hühnerpankreas nachgewiesen. Zur Messung der Bindung wird Tyr ${ }^{1}$-Somatostatin mit ${ }^{125}$ I radiomarkiert (Lactoperoxidase-Technik). Eine spezifische Radioaktivität von $18,5 \mathrm{MBq} / \mathrm{nmol}$ wird erreicht. Die maximale totale Bindung beträgt annähernd $0,17\left(\frac{B}{\bar{T}}\right)$ in Gegenwart von $30 \mathrm{mg} / 1$ pankreatischem Protein. Die spezifische Bindung beträgt 0,10 und ist nach Zugabe von $1 \mathrm{mg} / 1$ synthetischem cyclischen Somatostatin verdrängbar. Die dose-response-Kurve von synthetischem cyclischen Somatostatin liegt im Bereich 0,6-600 nmol/1. $\mathrm{Ca}^{2+}$ und reduziertes Thiolreagenz hemmt die Bindung, Insulin, Glucagon und Corticotropin (ACTH) zeigen eine schwache und Luliberin (LH-RH) sowie reduziertes Somatostatin (SRIF) weisen eine hohe Kreuzreaktivität auf. Das Molekulargewicht wird mittels Gelfiltration geschätzt: das spezifische Bindungsprotein wird bei einem $\mathrm{K}_{\mathrm{av}}=0,2$ mit einer Ultrogel ${ }^{\circledR}$ (AcA 54)-Säule eluiert. $M_{\mathrm{r}}=40000$.

Elektrophoretische Ėigenschaften des Bindungskomplexes und des mittels Polyacrylamidgel-Elektrophorese angereicherten Bindungsfaktors: Die relative Mobilität des [ ${ }^{125} \mathrm{I}-\mathrm{Tyr}^{1}{ }^{1}$ Somatostatin-Bindungskomplexes beträgt etwa 0,6; die der Bindungsproteinfraktionen 0,71 und 0,74. Die höchste relative spezifische Bindung wird in der $100000 \mathrm{~g}$ Cytoplasmafraktion gefunden. Die Bindung mit zellfreien Extrakten aus dem Bereich des Milzlappens ist 4-mal höher als in anderen Bereichen des Hühner-Pankreas.

\section{Introduction}

The tetradecapeptide somatostatin, which was originally identified in hypothalamic extracts, is distributed throughout the central nervous system, and is also found in the gastrointestinal tract and in the pancreas $(1-6)$.
Furthermore, a multitude of inhibiting effects of somatostatin are well documented (for review: see l.c. (7)). However, little is known about the mechanism of action of somatostatin at the cellular and subcellular level. In this context it may be of importance that a 
specific binding protein has been demonstrated in different organs (8).

It is also known that somatostatin inhibits secretion of glucagon and insulin in the islet cells of the pancreas (9). In addition to endocrine functions, a paracrine and/or local effect of somatostatin-producing pancreatic D-cells (10) on the glucagon- and insulin-secreting neighbouring cells can be assumed. Immunochemical investigations show that high concentrations of somatostatin are located in the chicken pancreas dark islet cell areas, where large amounts of D-cells can be found (11). The possibility, however, that somatostatin is secreted in connection with binding proteins has so far received little attention. Since the paracrine actions of somatostatin might be influenced by binding proteins, e.g. carriers and receptors, the biochemical characterization of those proteins is of importance.

We have now been able to demonstrate that a specific somatostatin binding factor occurs in dark islet cell areas of the chicken pancreas.

This paper characterizes the soluble somatostatin binding factor.

\section{Materials and Methods}

\section{Materials}

Cyclic somatostatin, cyclic $\mathrm{Tyr}^{1}$-somatostatin, and linear somatostatin were purchased from Serono (Freiburg). Lactoperoxidase (EC 1.11.1.7) and reference proteins for the molecular weight determinations were obtained from Boehringer (Mannheim); aprotinin (Trasylol ${ }^{\circledR}$ ), Bayer (Leverkusen); insulin, glucagon, luliberin (LH-RH), thyroliberin (TRH), Hoechst (Frankfurt); corticotropin, porcine (ACTH), Ferring (Kiel); AcA 54- ${ }^{\circledR}$ "Ultrogel", LKB (Sweden), and "Sephadex" gels, Pharmacia (Frankfurt); Ion-exchange resin (Dowex $1 \times 10$ ) and charcoal Norit $A$, Serva (Heidelberg) coated with $15 \%$ dextran $T \mathbf{4 0}$ obtained from Pharmacia (Frankfurt); $\mathrm{Na}^{125} \mathrm{I}$, Amersham-Buchler (Braunschweig); bovine serum albumin, Behring (Marburg). All other chemicals (p.a. grade) were purchased from Merck (Darmstadt) or Boehringer (Mannheim) unless otherwise specified in the text.

Since somatostatin readily absorbs to glass surfaces, incubations were carried out in "Minisorb" tubes from NUNC (Denmark).

\section{Radiolabeling}

Labeling of $\mathrm{Tyr}^{1}$-somatostatin with ${ }^{125} \mathrm{I}$ was performed according to the lactoperoxidase $/ \mathrm{H}_{2} \mathrm{O}_{2}$-technique (12). Dowex $1 \times 10$ anion exchange resin and Sephadex G-25 absorption chromatography were used for further purification of the labeled hormone (13).

\section{Preparation of cell-free extracts}

Adult domestic fowls (Warren-sex-sal-link) were decapitated and bled without anaesthesia. The pancreas was separated from the surrounding tissue. About $0.15 \mathrm{~g}$ of the splenic lobe area were cut, weighed and washed with $1 \mathrm{ml} 10 \mathrm{mmol} / 1$ tris (hydroxymethyl)-aminomethane/HCl buffer, $\mathrm{pH} 8.0,100-500 \mathrm{KIE}$ aprotinin. The pancreatic tissue was homogenized in a twentyfold volume of the same buffer by treatment ( 20 strokes, $1600 \mathrm{rpm}$ ) with a glass-Teflon-homogenator at $4{ }^{\circ} \mathrm{C}$. Fractions were frozen and stored below $-20^{\circ} \mathrm{C}$. Different areas of the pancreas were worked up in the same manner. Protein was measured according to the method of Bradford (14), Biorad (München).
Binding assay and separation of bound (B) and free $(F)$ somatostatin

Routinely the following assay was performed (tab. 1): The binding assays were performed with the crude supernatants (cell-free extracts) $600 \mathrm{~g}, 15000 \mathrm{~g}$, and $100000 \mathrm{~g}$. After $2 \mathrm{~h}$ incubation time at $4^{\circ} \mathrm{C}$, the reaction was stopped by addition of dextran-coated charcoal. The mixtures were agitated for 15 min using a "whirl-mix" and then centrifuged.

Radioactivity of supernatants and charcoal fractions were measured in an automatic gamma counter (Packard 5166) and the $B / T$-values (total radioactivity, $T=B+F$ ) were calculated.

Tab. 1. Routine procedure for the for the binding assay.

\begin{tabular}{|c|c|}
\hline $940 \mu \mathrm{l}-960 \mu \mathrm{l}$ & $\begin{array}{l}50 \mathrm{mmol} / 1 \text { tris (hydroxy methyl)-amino- } \\
\text { methane, } 10 \mathrm{mmol} / 1 \text { EDTA, } 1 \mathrm{~g} / \mathrm{l} \text { gelatin } \\
\text { pH } 8.0\end{array}$ \\
\hline $\begin{array}{l}20 \mu l \\
20 \mu l\end{array}$ & $\begin{array}{l}\text { synthetic cyclic somatostatin }{ }^{+}(1 \mu \mathrm{g}) \\
{\left[^{125} \mathrm{I}_{\left.-T^{2}{ }^{1}\right] \text { somatostatin }(200 \mathrm{~Bq})}\right.}\end{array}$ \\
\hline $20 \mu 1$ & $\begin{array}{l}\text { extract } \\
10-30 \mathrm{mg} / 1 \text { protein }\end{array}$ \\
\hline
\end{tabular}

+ To each second tube cold synthetic somatostatin was added. Specific binding $(B / T)$ was estimated corresponding to the $\%$-displacement compared with the tubes without excess cyclic somatostatin.

\section{Gel-filtration}

Gel chromatography was done with Ultrogel AcA 54. Phosphate buffer $0.01 \mathrm{~mol} / \mathrm{l} \mathrm{pH} 7.5$, was applied for elution and the absorption at $280 \mathrm{~nm}$ measured continuously unless described otherwise.

\section{Polyacrylamide disc gel electrophoresis}

Disc-electrophoresis was performed as described by Davis (15), pH 8.9-75 g/l. A flat gel (3 mm) apparatus from Desaga (Heidelberg) was used. Volumes of 20-60 $\mu \mathrm{l}(1-2 \mathrm{~g} / \mathrm{l}$ protein) of the binding fractions were carefully pipetted into prepolymerized pockets of the spacer gel. The samples were mixed with $5 \mu \mathrm{l}$ $1 \mathrm{~mol} / \mathrm{l}$ sucrose to avoid rapid diffusion into the electrode buffer.

Electrophoresis was started with a voltage of $250 \mathrm{~V}$ for the first $5 \mathrm{~min}$, then the potential was stepwise elevated up to $500 \mathrm{~V}$. The electric current decreased slightly during a separation time of $2 \mathrm{~h}$. The flat gel was cut longitudinally and incubated in a fixative stain solution: Coomassie Brilliant Blue $R 250(2.5 \mathrm{~g} / \mathrm{l})$ in $125 \mathrm{~g} / 1$ trichloroacetic acid, or Amido-Black $10 \mathrm{~B}$ in $70 \mathrm{~g} / 1$ acetic acid. The stained gels were washed and scanned at 580 $\mathrm{nm}$, or $620 \mathrm{~nm}$, respectively, in a gel scanner from Zeiss. The longitudinal gels were sliced ( $2 \mathrm{~mm}$ pieces) and radioactivity $\left({ }^{125} \mathrm{I}\right)$ was measured in an automatic gamma counter (Packard 5166).

\section{Results}

Interaction of $\left[{ }^{125} I-T y r^{1}\right]$ somatostatin with binding factor from chicken pancreas

Binding of [ $\left.{ }^{125}{ }^{2}-\mathrm{Tyr}^{1}\right]$ somatostatin to fractions of cellfree extracts of the chicken pancreas could be demonstrated. Maximal binding was found with "retarded" $\left[{ }^{125}{ }^{-T}\right.$ Tyr $\left.^{1}\right]$ somatostatin fractions of Sephadex G-25 adsorption chromatography (fig. 1). Specific radioactivity of $18.5 \mathrm{MBq} / \mathrm{nmol}$ was achieved. 


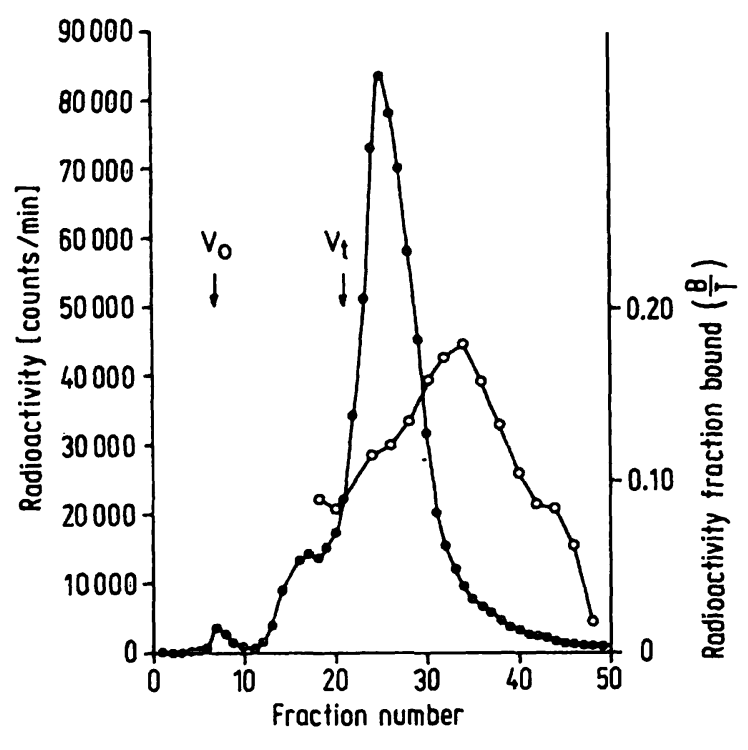

Fig. 1. Adsorption chromatography (Sephadex G-25) elution pattern of [ ${ }^{125} \mathrm{I}-\mathrm{Tyr}^{1}$ ] somatostatin.

The reaction mixture $(1 \mathrm{ml}=2 \mathrm{MBq})$, prepared by the lactoperoxidase $/ \mathrm{H}_{2} \mathrm{O}_{2}$-technique, as described in Materials Methods, was applied to a column $(1.5 \times 30 \mathrm{~cm})$ of Sepha$\operatorname{dex} \mathrm{G}-25$. The column was eluted with $1 \mathrm{~g} / \mathrm{l}$ gelatin in $0.05-0.2 \mathrm{mmol} / 1$ ammonium acetate $\mathrm{pH} 6.7$ within $2 \mathrm{~h}$ at room temperature. $2.5 \mathrm{ml}$ fractions were collected and $50 \mu \mathrm{l}$ aliquots were measured in a scintillation counter (Packard 5166), $\mathrm{V}_{\mathrm{o}}$ indicates the dextran blue 2000 and $V_{t}$ the $\mathrm{Na}^{125}$ I fraction.

$\bullet-\bullet$ eluted radioactivity

0 - 0 the total binding $B / T$ of each second fraction $(5 \mu \mathrm{l})$ incubated with cell-free extract of the chicken pancreas $\left(P_{3}\right) 20 \mathrm{~h}$ at $4^{\circ} \mathrm{C}$.

The amounts of bound radioactivity were determined as described in Materials and Methods. Each point gives the mean of the duplicate values. Maximal total binding is achieved at the retarded fraction No. 34 .

Under standard incubation conditions, maximal binding is about 0.17 (bound/total $=\mathrm{B} / \mathrm{T}$ ), and unspecific binding (samples without binding factor) ranges from $0.05-0.09$. Weir et al. (11) found a higher amount of somatostatinlike immunoreactivity in the splenic lobe than in other areas of the chicken pancreas. In figure 2 a scheme of chicken pancreas is demonstrated.

A schematic cutting out of the islets of Langerhans is shown in figure $2 \mathrm{~b}$ and the local regulatory connections are shown in figure $2 \mathrm{c}$. The interactions of $\left[{ }^{125} \mathrm{I}_{-T y r^{1}}\right]-$ somatostatin were measured with homogenates and/or cell-free extracts from different areas of the chicken pancreas. Binding of somatostatin is 4 -fold in the splenic lobe area $\left(\mathrm{P}_{3}\right)$ compared with inferior parts of the chicken pancreas $\left(\hat{\mathrm{P}}_{2}\right.$ and $\left.\mathrm{P}_{1}\right)$ (fig. $2 \mathrm{a}$ ).

Bovine serum albumin as well binds $\left[{ }^{125} \mathrm{I}-\mathrm{Tyr}^{1}\right]$ somatostatin, as shown in figure 3 . However, in this case, an increase of the binding can only be achieved at higher concentrations $(>1 \mathrm{~g} / 1)$. Ovalbumin shows no concentration-dependent binding.
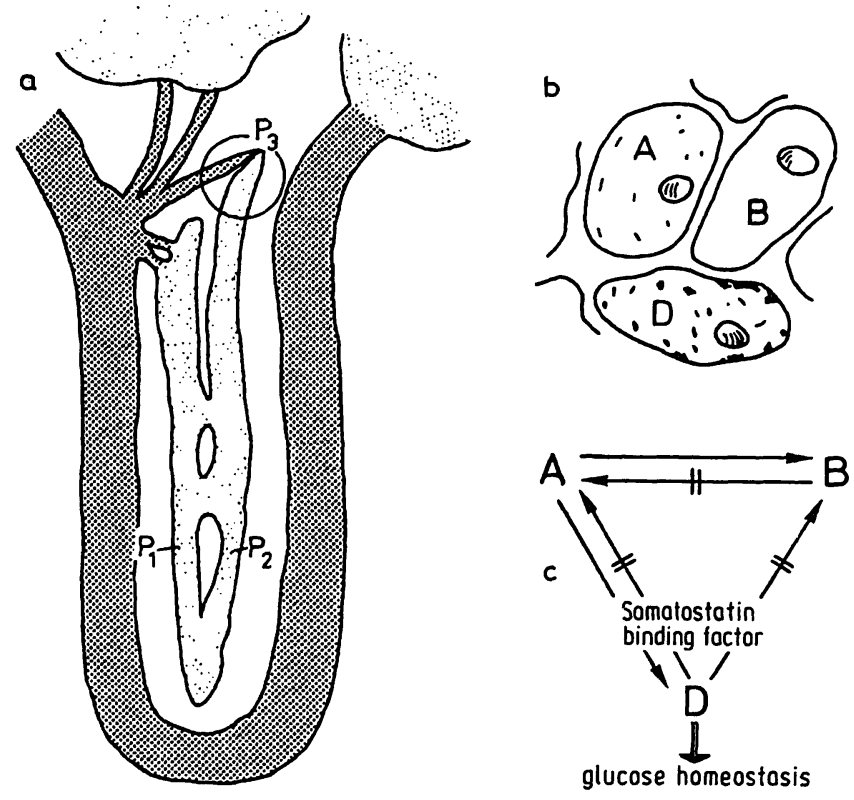

Fig. 2. Schematic drawings showing

a) chicken pancreas with the splenic lobe area (circle) where high amounts of dark islet cells are located, "P $\mathrm{P}_{3}$ ";

b) neighbouring islet cells producing glucagon (A), insulin (B), and somatostatin (D);

c) the regulation triangle, where somatostatin (D) inhibits glucagon (A) and insulin (B) secretion (negative feedback), which in total is responsible for glucose homeostasis. The somatostatin binding factor is linked to somatostatin secretion of the D-cells.

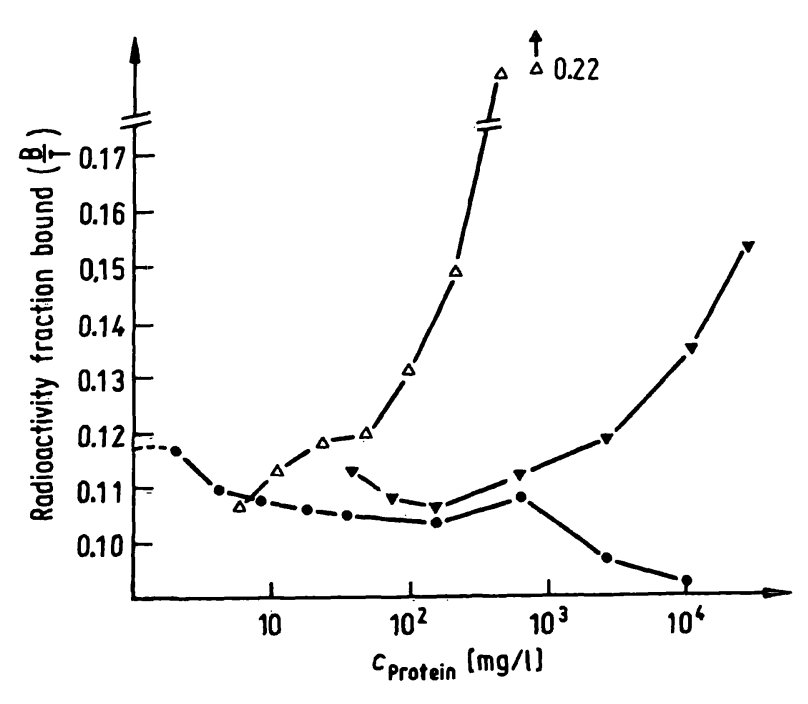

Fig. 3. Binding $\mathrm{B} / \mathrm{T}$ of $\left[{ }^{125} \mathrm{I}-\mathrm{Tyr}^{1}\right]$ somatostatin with cell-free extracts $(100000 \mathrm{~g})$ of the splenic lobe area of chicken pancreas $\left(\mathrm{P}_{3} ; \Delta-\Delta\right)$, bovine serum albumin $(\Delta-\Delta)$, and ovalbumin $(\bullet-\bullet)$. Different concentrations of the proteins were incubated under standard conditions and bound and free somatostatin were separated applying the oharcoal technique (see Materials and Methods). Each point gives the mean of the duplicate values. 


\section{Specificity and dose-response of binding}

Addition of an excess $(1 \mathrm{mg} / \mathrm{l})$ of cold synthetic cyclic somatostatin to the incubation medium results in a displacement of ${ }^{125} \mathrm{I}$-labeled $\mathrm{Tyr}^{1}$-somatostatin. The relative amount of displaceable radioactivity by synthetic cyclic somatostatin is defined as specific binding. Maximal values achieved are about $0.10\left(\frac{\mathrm{B}}{\mathrm{T}}\right)$.

This maximal binding is reversible as it could be demonstrated by coincubation and preincubation experiments with $\left[{ }^{125} \mathrm{I}-\mathrm{Tyr}^{1}\right]$ somatostatin. However, when cold cyclic somatostatin is preincubated for about $30 \mathrm{~min}$ the specific binding (as defined in this paper) increases to $0.11-0.14\left(\frac{B}{T}\right)$. It was found that $0.01-0.04\left(\frac{B}{T}\right)$ of this binding is irreversible.

Usually coincubation of labeled and unlabeled ligands was performed (tab. 1).

The $\mathrm{pH}$-optimum is at $\mathrm{pH} 8$, and equilibrium is reached after $20 \mathrm{~h}$ incubation time at $4{ }^{\circ} \mathrm{C}$. For routine determination, a $2 \mathrm{~h}$ reaction time has been employed since 0.90 of the maximal binding is achieved after this incubation time.

Table 2 summarizes specific binding values dependent on $\mathrm{Ca}^{2+}$ and thiol-reagents, including linear somatostatin, which contains free thiol-groups. Thus, it has been demonstrated that EDTA is necessary for optimal binding, and $\mathrm{Ca}^{2+}$ ions are inhibitory.

The binding is inhibited by compounds containing reducing thiolgroups. This effect is observed not only in the presence of reducing agents such as dithiothreitol, but also with reduced glutathione (GSH) and reduced somatostatin (linear form). Oxidized glutathione (GSSG) does not inhibit the specific binding.

The dose-dependent inhibition of the specific binding between $\left[{ }^{125} \mathrm{I}-\mathrm{Tyr}^{1}\right]$ somatostatin and cell-free extract of the splenic lobe area $\left(\mathrm{P}_{3}\right)$ by synthetic cyclic somatostatin is illustrated in figure 4.

$50 \%$-displacement occurs in the region of $15 \mathrm{nmol} / \mathrm{l}$. Cyclic somatostatin and linear somatostatin show parallel dose-response curves, but the linear peptide has a 10 -fold weaker (50\%)displacement.

Tab. 2. Influence of $\mathrm{Ca}^{2+}$ and thiol reagents on the binding of radioiodinated $\mathrm{Tyr}^{1}$-somatostatin to a cell-free extract of " $P_{3}$ ". $n=4$.

\begin{tabular}{lll}
\hline & $\begin{array}{l}\text { Concentration } \\
(\mathrm{mmol} / \mathrm{l})\end{array}$ & $\begin{array}{l}\text { Specific binding } \\
\mathrm{B} / \mathrm{T}(\%) \\
(\mathrm{x} \pm \mathrm{s})\end{array}$ \\
\hline Standard procedure & - & $10.0 \pm 1.4$ \\
No EDTA & - & $5.0 \pm 0.97$ \\
Ca ${ }^{2+}$ & 1 & $6.4 \pm 0.35$ \\
Dithiothreitol & 2 & $2.0 \pm 0.56$ \\
Glutathione (reduced) & 0.2 & $0.0 \pm 0.21$ \\
Glutathione (oxidized) & 0.2 & $9.0 \pm 0.98$ \\
Linear somatostatin & 0.006 & $3.4 \pm 0.11$ \\
\hline
\end{tabular}

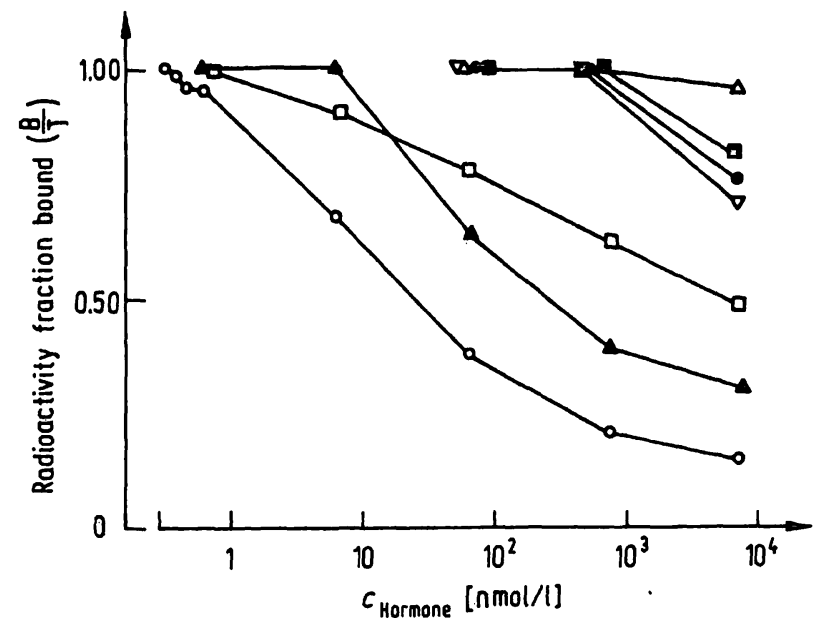

Fig. 4. Dose-response curves of the protein binding assay for cyclic somatostatin and cross-reactivity of other peptides. Cell-free extracts of " $\mathrm{P}_{3}$ " ( $30 \mu \mathrm{g}$ protein) were assayed with [ ${ }^{125} \mathrm{I}_{\text {-Tyr }}{ }^{1}$ ] somatostatin ( $200 \mathrm{~Bq}$ from fraction 34 , G-25 chromatography) in the presence of cyclic somatostatin ( $(0-0)$, linear somatostatin ( $\triangle \perp$ incubations under $\mathrm{N}_{2}$-atmosphere), luliberin $(\square-0)$, corticotropin $(\nabla-\nabla)$, glucagon $(\bullet-\bullet)$, insulin $(\square-\square)$, thyroliberin $(\Delta-\Delta)$, each $0.6-6000 \mathrm{nmol} / \mathrm{l}$. Maximal specific binding was $0.07(\mathrm{~B} / \mathrm{T})$.

The incubation conditions are described in Materials and Methods. The concentrations of the added peptides are plotted logarithmically on the abscissa. $B / T$ values were calculated and the blank value (sample without binding protein) is subtracted. Each point gives the mean of duplicates.

Cross-reactivity also can be observed with luliberin (LH-RH), which causes 50\%-displacement at $500 \mathrm{nmol} / \mathrm{l}$. Thyroliberin (TRH), insulin, glucagon, and corticotropin (ACTH) do not interfere effectively.

The association constant $\left(\mathrm{K}_{\mathrm{a}}\right)$ is determined from a Scatchard plot (fig. 5). The bound (B)/free (F)-values are plotted as a function of the bound ligand concentration. There is a linear range with $\mathrm{K}_{\mathrm{al}}=1.8 \cdot 10^{9} \mathrm{l} / \mathrm{mol}$ and another one at higher concentrations with $\mathrm{K}_{\mathrm{a} 2}=8.2 \cdot 10^{7} \mathrm{l} / \mathrm{mol}$.

\section{Subcellular localization of pancreatic somatostatin binding factor}

In order to find out whether the binding factor is a cell membrane, particle-bound substance (e.g. receptor) or whether it is a soluble cytoplasmatic protein, fractionating centrifugation was performed. Binding in supernatants and pellets was determined after differential centrifugations at $600 \mathrm{~g}, 15000 \mathrm{~g}$, and $100000 \mathrm{~g}$. The total binding increases with the $g$-number and is highest in the $100000 \mathrm{~g}$-supernatant. The binding capacity of the corresponding pellets remains constant. This suggests that the binding factor is of cytoplasmic origin.

In another attempt to enrich the solubilized binding factor in the cytosol fractions, the protein-solubilizing agent, Triton X-100, was employed. Splenic lobe area 


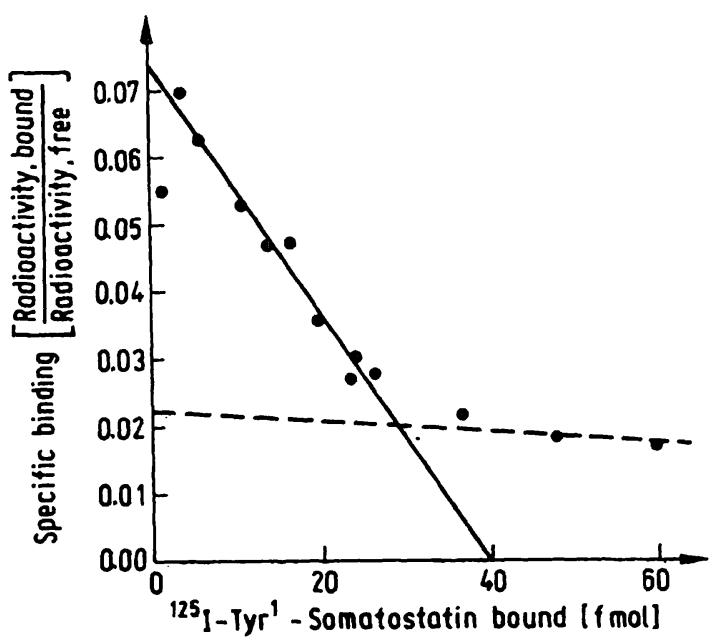

Fig. 5. Scatchard plot of somatostatin binding. Different concentrations of $\left[{ }^{125} \mathrm{I}-\mathrm{Tyr}^{1}\right]$ somatostatin from the G-25 chromatography (fraction 34, see fig. 1). were incubated with cell-free extracts of the chicken pancreas " $P_{3}$ " (10 $\mu \mathrm{g}$ protein). The routine assay conditions were performed, except that the incubation time was prolonged to $20 \mathrm{~h}$. The ratio of bound $\left[{ }^{125}{ }^{-T y r^{1}}\right]$ somatostatin to free hormone is plotted as a function of specific binding. Two association constants can be extrapolated: $\mathrm{K}_{\mathrm{a1}}=1.8 \cdot 10^{9} 1 / \mathrm{mol}\left(\right.$ or $\left.\mathrm{K}_{\mathrm{d} 1}=5.5 \cdot 10^{-10} \mathrm{~mol} / \mathrm{l}\right)$ and $\mathrm{K}_{\mathrm{a} 2}=8.2 \cdot 10^{7} \mathrm{l} / \mathrm{mol}$ (or $\mathrm{K}_{\mathrm{d} 2}=1.2 \cdot 10^{-8} \mathrm{~mol} / \mathrm{l}$ ). The specific radioactivity was calculated to be $6 \mathrm{MBq} /$ nmol. Each point gives the mean of duplicate values.

$\left(P_{3}\right)$ extract was treated with $10 \mathrm{ml} / 1$ Triton $\mathrm{X}-100$ during homogenization.

Following a standard assay, radioactivity was measured in the $15000 \mathrm{~g}$ fraction. The remaining bound radioactive somatostatin is significantly higher $(p<0.02)$ in the untreated pellet compared with the Triton X-100treated pellet. In both cases, addition of cold somatostatin before centrifugation causes an increase of binding (fig. 6a).

In contrast, when cold somatostatin is added to the supernatants, suppression is achieved (fig. 6b). Maximal binding capacity is about 0.206 , and this is significantly higher $(p<0.01)$. Suppression in the absence and presence of Triton X-100 is 0.076 and 0.032 , respectively (fig. 6b). This again suggests that the major binding component is a soluble cytosol molecule.

\section{Characterization by gel-filtration}

For further characterization, the cell-free extract of " $P_{3}$ " was fractionated by gel filtration, and the specific binding was measured in the fractions.

AcA 54 with a separation range of 5000-70000 was used. The $280 \mathrm{~nm}$ absorption-diagram of the AcA 54chromatography and the corresponding binding values are shown (fig. 7). In this experiment, incubation of the $100000 \mathrm{~g}$-supernatant with somatostatin was done after column chromatography and concentrating of the

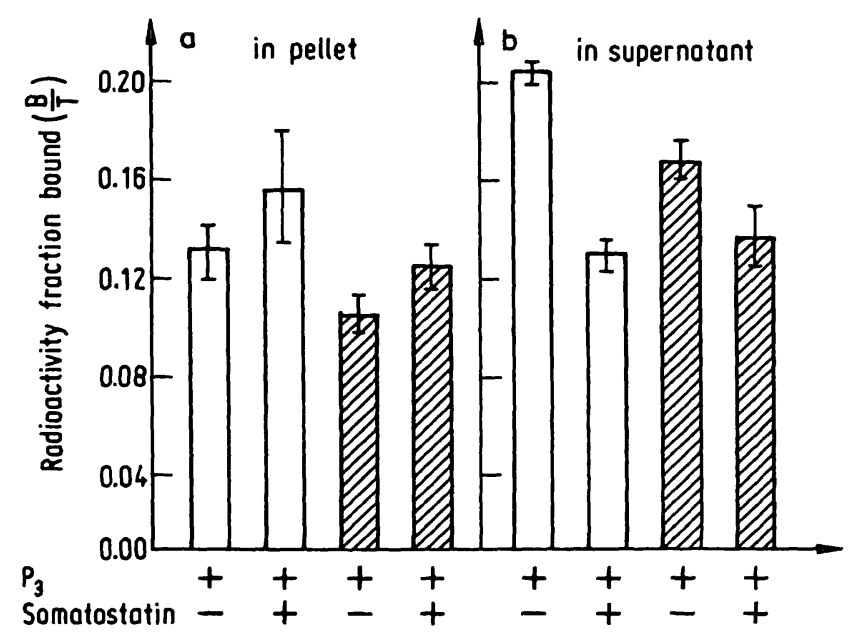

Fig. 6. Binding $(B / T)$ of somatostatin with crude homogenate of chicken pancreas " $P_{3}$ " with and without Triton $\mathrm{X}-100$. Preparation of crude homogenate was carried out as described in Materials and Methods. One sample was homogenated in the presence of $10 \mathrm{ml} / 1$ Triton $\mathrm{X}-100.20 \mu \mathrm{l}$ (= $52 \mu \mathrm{g}$ protein) of an untreated (white columns) and $20 \mu \mathrm{l}$ of the Triton X-100 sample (black columns) were added to the routine binding assay (Tab. 1).

To each second tube $16 \mu \mathrm{l}$ solution of cold cyclic somatostatin was added. After $2 \mathrm{~h}$ incubation, samples were centrifuged at $15000 \mathrm{~g}$ for $10 \mathrm{~min}\left(4^{\circ} \mathrm{C}\right)$ and radioactivity was measured in the pellets (fig. 6a). The supernatants were treated with charcoal, centrifuged, radioactivity was measured and B/T-values were calculated. (fig. 6b), S.D., $n=5$. Suppression was achieved only in the supernatants, and was highest in the samples without Triton X-100.

fractions by freeze-drying. The results indicate elution of the binding factor at $K_{a v}=0.23$. This suggests a molecular weight of approximately 40000 when compared with the standard curve established with reference proteins (fig. 7). Although the addition of Triton-X-100 had been reported to have an influence on gel filtration patterns (16) it was found that the Triton X-100-treated samples have the same specific binding elution peak at $\mathrm{K}_{\mathrm{av}}=0.23$.

\section{Characterization by polyacrylamide disc gel electro- phoresis}

In order to elucidate electrophoretic properties of the binding factor by a high resolution separation technique, polyacrylamide disc gel electrophoresis was performed. Typical electropherograms of radioactive somatostatin and the binding incubates are presented in figure 8 . Two main peaks are located: the first at relative mobility $\sim 0.6$ and the second at $\cong 0.36$ (fig. 8,1). For comparison a run with radioactive somatostatin (SRIF) is presented in figure 8,2 . Here a peak appears at $\cong 0.36$. This peak can be totally extracted by treating the gels with trichloroacetic acid (fig. 8,3 and 8,4). However, the radioactivity at $\sim 0.6$ is not extractable and indicates a denatured stable binding complex (fig. 8,3). 

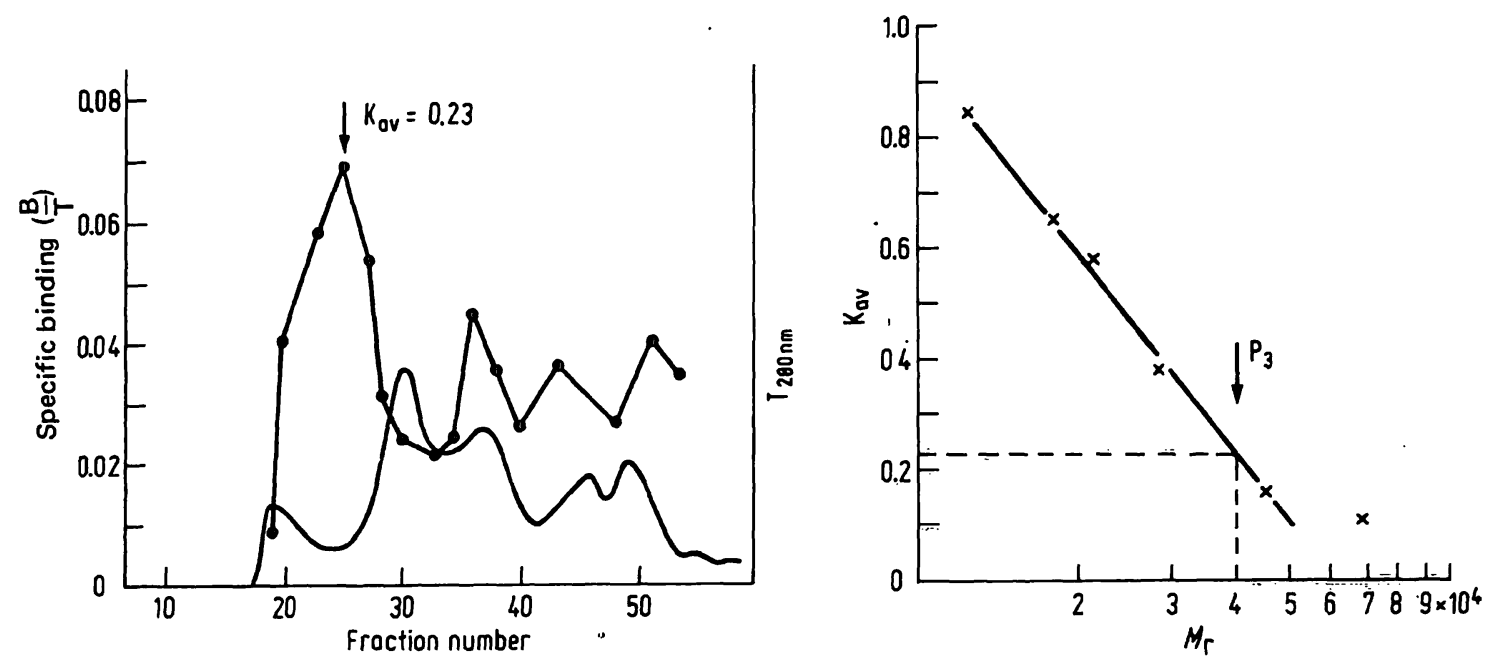

Fig. 7. Gel-filtration (Ultrogel AcA 54) of cell-free extract " $\mathrm{P}_{3}$ " $(100000 \mathrm{~g})$ and relative molecular mass $\left(M_{\mathrm{r}}\right)$ estimation.

$13.6 \mathrm{mg}$ protein $(2 \mathrm{ml})$ were separated on an $1.6 \times 61 \mathrm{~cm}$ column, $2 \mathrm{ml}$ fractions were collected and freeze-dried. The void volume appeared at fraction 20 and the "salt" peak at fraction 51. For further detail concerning gel-filtration see Materials and Mathods.

Transmission at $280 \mathrm{~nm}$

Aliquots of several fractions were incubated with $\left[{ }^{125} \mathrm{I}_{-} \mathrm{Tyr}^{1}\right]$ somatostatin under standard conditions and the specific binding

Determinations of relative molecular mass $\left(M_{\mathrm{r}}\right)$ were carried out by comparison with $\mathrm{K}_{\mathrm{av}}$-values* $\left(\mathrm{K}_{\mathrm{av}}=\frac{\mathrm{V}-\mathrm{V}_{\mathrm{o}}}{\mathrm{V}_{\mathrm{t}}-\mathrm{V}_{\mathrm{O}}}\right)$ of cytochrome

c (12 500), myoglobin (17 800), trypsin inhibitor from soybean (21 000), trypsin inhibitor from egg protein (28 000), ovalbumin $(45000)$, and bovine serum albumin $(68000)$, as well as dextran blue $2000\left(\mathrm{~V}_{\mathrm{o}}\right)$ and $\mathrm{Na}^{125} \mathrm{I}\left(\mathrm{V}_{\mathrm{t}}\right)$ as reference materials. $* \mathrm{~V}=$ elution volume.

Figure 9 shows simultaneous runs of a disc electrophoresis with seven Ultrogel-AcA-54 fractions (the gel filtration elution diagram is not shown here).

The highest radioactivity appears in a fraction corresponding to $\mathrm{K}_{\mathrm{av}}=0.23$ in gel filtration; this was shown in experiments in which the specific binding was tested after Ultrogel-fractionation (fig. 7). When the fraction corresponding to $\mathrm{K}_{\mathrm{av}}=0.2$ is further separated by discelectrophoresis, the larger peaks at lower relative mobilities suggest that the pancreatic binding factor in the $\mathrm{K}_{\mathrm{av}}=0.2$-fraction is still heterogeneous (fig. 10).

The protein peaks at relative mobilities $=0.71$ and $=0.74$ contain the pancreatic binding factor. This is suggested by the fact that the unstained halves of the gel slices bind labeled $\mathrm{Tyr}^{1}$-somatostatin at the same relative mobilities as the above mentioned proteins (Diel \& Schneider, unpublished work).

\section{Discussion}

Specific binding between cyclic somatostatin and a soluble binding factor has been detected in the chicken pancreas. The highest concentrations of this binding factor have been found in the splenic lobe area $\left(\mathrm{P}_{3}\right)$. This coincides with a preponderance of the somatostatinproducing D-cells in this part of the organ $(11 ; 17)$.

Recently, Ogawa et al. (8) found a specific somatostatin binding protein while investigating several tissues, mainly from the female rat. Schonbrunn \& Tashịan (18) described somatostatin receptor binding with cells of the rat pituitary. In both cases, specificity of the binding could be demonstrated. But the differences in the reported thermodynamic data suggest differences in the nature of somatostatin binding.

As the specific binding capacity which was measured in this work $\left(\frac{B}{T}=0.10 / 30 \mu\right.$ protein $)$ is relatively low compared with the results of Ogawa et al. (8) (0.15-0.36/ $10 \mu \mathrm{g}$ protein) several possible interferring factors should be recognized before further discussion of the binding data:

a) Somatostatin was radiolabeled at the $\mathrm{Tyr}^{1}$-residue of the cyclic tetradecapeptide. This side chain of somatostatin is not as important as other parts for the biological activity of the hormone (19). It just may be essential for the binding properties described here. Therefore, derivatisation and especially addition of iodine to the Tyr-residue at the $\mathrm{N}$-terminal may diminish the specific binding with the pancreatic binding factor.

In addition, heterogeneity of $\left[{ }^{125} \mathrm{I}-\mathrm{Tyr}^{1}\right]$ somatostatin should be taken into account. In recent work, this phenomenon is demonstrated by isoelectric focusing analysis (13), although purification of the labeled $\mathrm{Tyr}^{1}$ somatostatin by G-25 Sephadex adsorption chromatography reveals only one main peak, which is retarded (fig. 1).

b) A paradoxical effect was observed when cold cyclic somatostatin was added to the incubation medium. No 


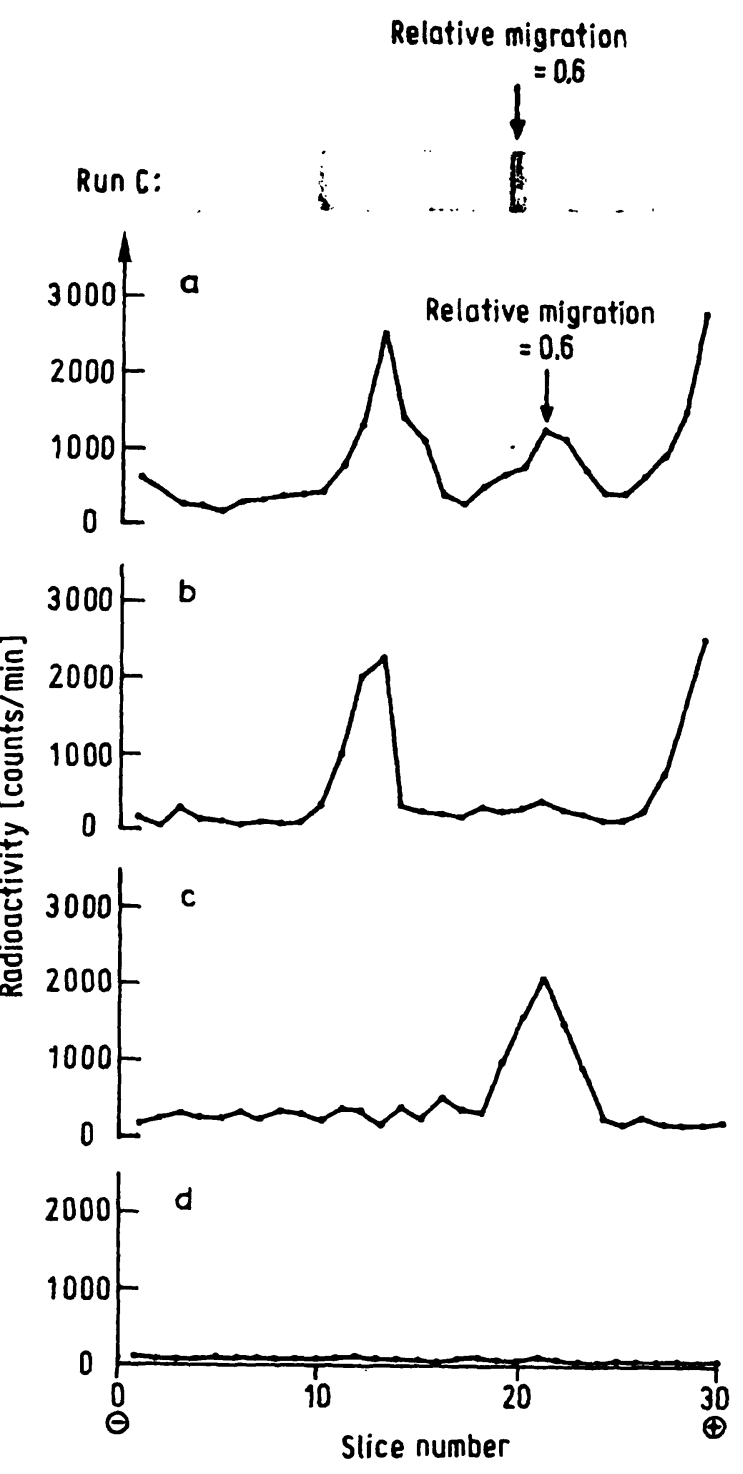

Fig. 8. Polyacrylamide disc gel electrophoresis of somatostatinbinding complex from chicken pancreas " $P_{3}$ ". Disc electrophoreses were performed simultaneously in a flat gel apparatus (Desaga-Heidelberg, Germany) according to the system of Davis (15) pH 8.9-7.5\%. Undiluted homogenate of chicken pancreas " $P_{3}$ " was incubated with $\left[{ }^{125} \mathrm{I}_{-} \mathrm{Tyr}^{1}\right]$ somatostatin $(3500 \mathrm{~Bq})$ for $1 \mathrm{~h}$ at room temperature in $100 \mu \mathrm{l}$ and total volume filled up to $1 \mathrm{ml}$ with assay buffer (tab. 1). $20 \mu 1$ samples were applied to the spacer gel. Electrophoresis was carried out as described in Materials and Methods.

a) Total incubation medium (binding complexes at relative migration of 0.36 and 0.6 )

b) $\left[{ }^{125}\left[-T_{y} \tilde{r}^{1}\right]\right.$ somatostatin (ielative migration $=0.36$ )

c) and d) were identical to a) and b) but treated with $1 \overline{25} \mathrm{~g} / \mathrm{l}$ trichloroacetic acid (after electrophoresis) overnight at room temperature. The gels were sliced in $2 \mathrm{~mm}$ pieces, and radioactivity was measured.

Gels were stained overnight with Coomassie Brilliant Blue $\mathrm{R}-250$. One typical run is presented.

displacement occurred, and even a paradoxical increase of binding was demonstrated in figure 6 , where redissolved cell pellets were incubated with an excess of cold cyclic somatostatin.
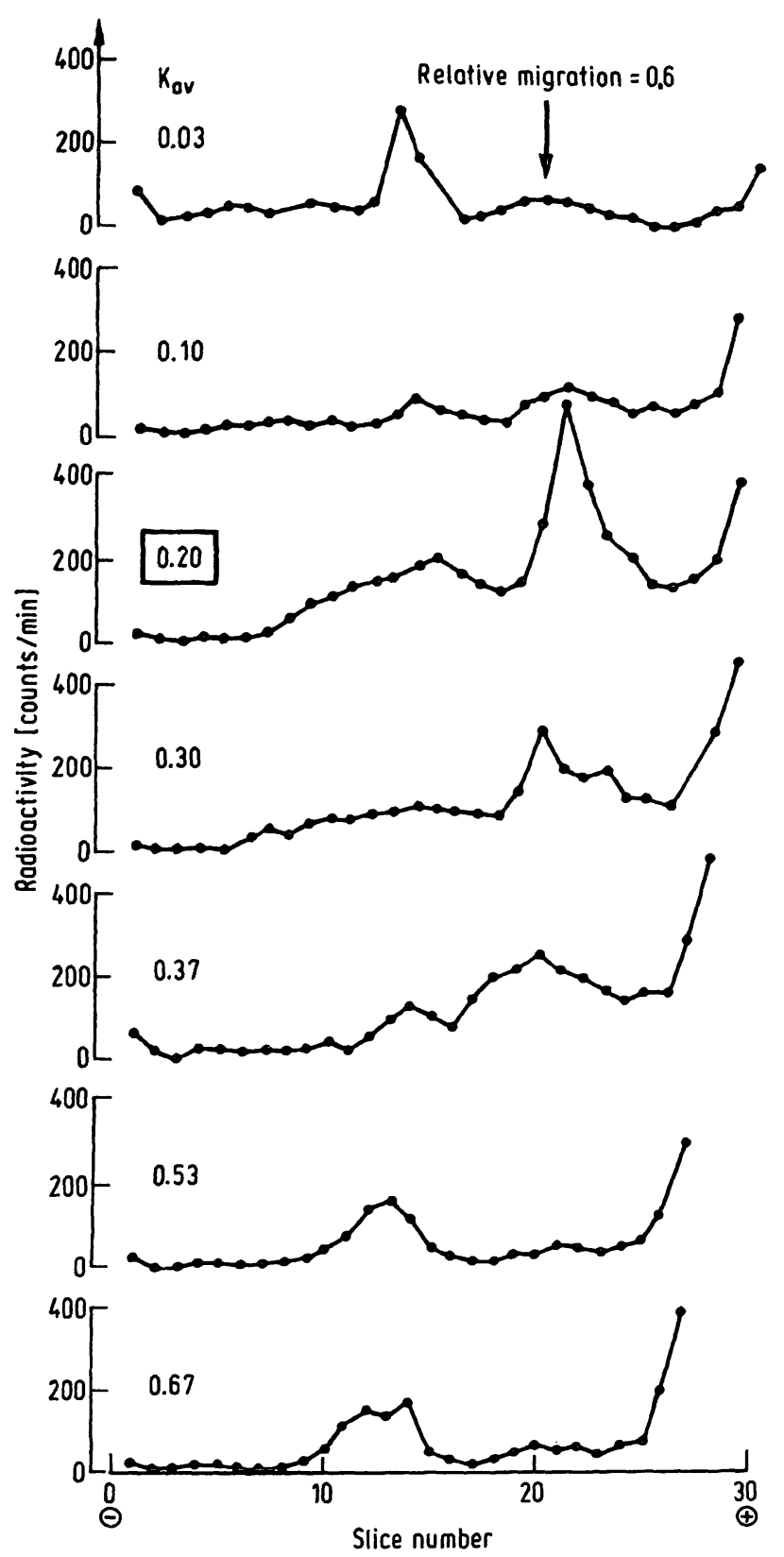

Fig. 9. Polyacrylamide disc gel electrophoresis of seven fractions of gel-filtered somatostatin-binding complex of chicken pancreas " $P_{3}$ ".

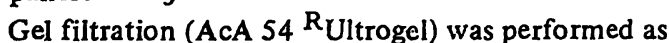
described in figure 7. Disc electrophoresis is similar to that demonstrated in figure 8. The freeze-dried fractions of the gel filtration were redissolved in $50 \mu \mathrm{l}$ assay-buffer (tab. 1) and incubated with $10 \mu 1\left[^{125} I-T_{y r}^{1}\right]$ somatostatin $(900 \mathrm{~Bq})$ for $1 \mathrm{~h}$ at room temperature. $30 \mu \mathrm{l}$ aliquots were applied. The unstained gels were sliced and radioactivity was measured as described in Materials and Methods. The fraction $\mathrm{K}_{\mathrm{av}}=0.2$ corresponds to the maximal binding (peak) in figure 7 .

The possibility that somatostatin induces a positive cooperation should be considered, but another explanation is given by the fact that somatostatin polymerizes to a high molecular compound, as observed in vitro (20) and in vivo (21). 


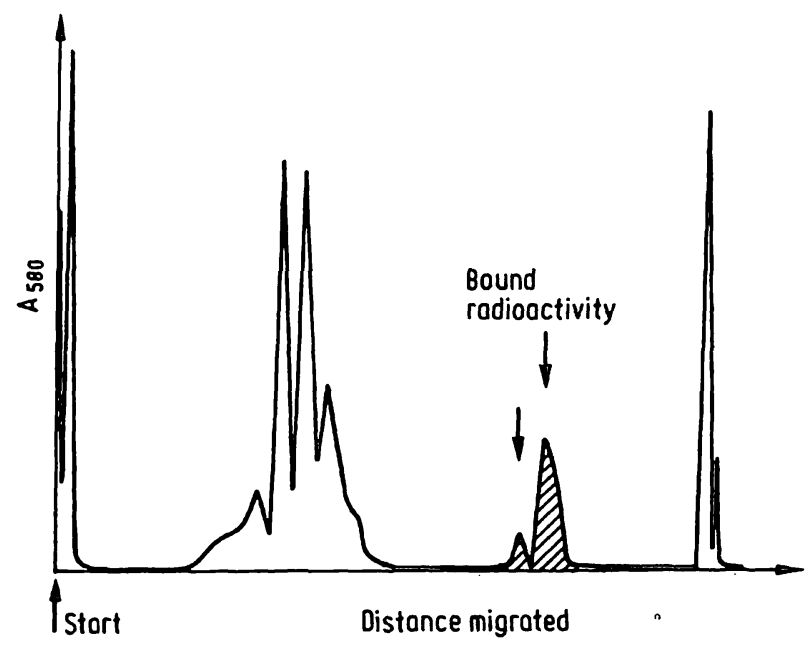

Fig. 10. Polyacrylamide disc gel electrophoresis of the pancreatic " $\mathrm{P}_{3}$ " somatostatin binding factor after gel filtration $\left(K_{\mathrm{av}}=0.2\right)$.

The fraction at $\mathrm{K}_{\mathrm{av}}=0.2$ of the gel filtration was electrophorized and one half of the gel (longitudinal) was treated with Coomassie Brilliant Blue R-250 and the other one was incubated in $50 \mathrm{kBq}\left[{ }^{125} \mathrm{I}_{\mathrm{I}} \mathrm{Tyr}^{1}\right]$ somatostatin (total volume $24 \mathrm{ml}$ assay buffer for $1 \mathrm{~h}$ at room temperature). Radioactivity and absorbance at $580 \mathrm{~nm}$ were measured as described in Materials and Methods. The arrows indicate the peaks which bind $\left[{ }^{125}{ }^{\mathrm{I}-\mathrm{Tyr}^{1}}{ }^{1}\right.$ somatostatin significantly $(\mathrm{p}<0.01)$.

The exact nature of the self-polymerization is controversial. On one hand, Spiess \& Vale (22) found that big pancreatic somatostatin, as already supposed by Arimura et al. (5), can be converted into the small form, which is eluted with the tetradecapeptide by gel filtration. On the other hand, Harris et al. (23), as well as Kronheim et al. (24) and Conlon et al. (25) detected high molecular somatostatin-like immunoreactivity (SLI) in plasma $\left(M_{\mathrm{r}}=100000\right)$ and suggested that somatostatin binds to macromolecular compounds, the nature of which is presently unknown.

c) Unspecific binding with e.g. bovine serum albumin and ovalbumin (fig. 3) and cross-reactivity with other ligands, as demonstrated in dose-response experiments (fig. 4), may increase the interferring reactivities.

Weak cross-reactivity with glucagon, insulin and corticotropin has been measured. The remarkably high inhibition by the hypothalamic hormone luliberin is in contrast to the weak effect of thyroliberin. Whether this difference has biological relevance remains unknown.

Nevertheless, several of our results are in good agreement with the work of Ogawa et al. (8) and Ogawa et al. (26). These authors reported that $\mathrm{Ca}^{2+}$ inhibits and EDTA induces the binding. This corresponds to our own observations (tab. 2) and recently was described by Arimura et al. (27) for immunochemical binding.

The disulfide bridge of the somatostatin molecule is likely to play a role in the interaction mechanism (tab. 2). Ogawa et al. (8) suggest a two-step reaction, one reversible event and another irreversible step, which includes the thiol-groups.

Experiments applying the reduced linear form of somatostatin (two HS-groups) show a parallel, but less sensitive dose-response curve compared with the oxidized cyclic conformer (fig. 4). These experiments were performed under nitrogen. Thus the reoxidation to cyclic somatostatin is unlikely. As reduced glutathione (GSH) inhibits the binding totally and reduces the S-S-bridge of cyclic somatostatin spontaneously (experiments with NADPglutathione oxidoreductase EC 1.6.4.2, not presented) it might be suggested that other amino acid residues are involved in the binding mechanism.

The complexity of the binding mechanism is supported by the results of the Scatchard plot (fig. 5). Two dissociation constants are calculated, $\mathrm{K}_{1}=5.5 \cdot 10^{-10} \mathrm{~mol} / \mathrm{l}$, which is similar to that found by Schonbrunn \& Tashjian (18) for receptor binding, and $\mathrm{K}_{2}=1.2 \cdot 10^{-8} \mathrm{~mol} / \mathrm{l}$, which is similar to that calculated for the cytosol binding protein presented by Ogawa et al. (8). In recent work Leitner et al. (28) found $\mathrm{K}_{1}=3.3 \cdot 10^{-8} \mathrm{~mol} / 1$ and $\mathrm{K}_{2}=7.7 \cdot 10^{-6} \mathrm{~mol} / 1$ for binding at anterior pituitary plasma membranes. For further characterization of the pancreatic binding factor column chromatography was performed. Although this gel filtration technique is similar to that which was carried out by Ogawa et al. (8), there is a discrepancy between our own molecular weight estimation $\left(M_{\mathrm{r}}=40000\right)$ and that reported by these authors $\left(M_{\mathrm{r}}=80000\right)$. In our work, an Ultrogel AcA 54 separation range 5000-70 000 and different elution systems were used. Additional experiments have to be done for a precise estimation of the molecular weight.

In addition, fractional centrifugation and treatment with solubilizer Triton X-100 were performed. Highest values of specific binding were found in the $100000 \mathrm{~g}$ cytosol fractions, which were free from mitochondria and membrane fragments (electron microscopy experiments, supplied by Dr. H. Pickartz). Since it was impossible to enrich the binding capacity by treatment of " $\mathrm{P}_{3}$ " extract with Triton X-100, it can be suggested that the binding factor is a soluble and not a particle bound (e.g. receptor) protein.

The disc electrophoresis experiments, which are presented in figures 8-10, indicate the existence of a stable soluble somatostatin binding complex. The relative mobility is about 0.6. Ogawa et al. (26) reported $\sim 0.7$.

As monomeric somatostatin possesses a high isoelectric point, 9.5, Diel et al. (13), and 10-10.4, Conlon et al. (25), it does not migrate into the polyacrylamide gel unter the described circumstances. However, extractable radioactivity appears in a distinct peak, relative mobility $=0.36$, when running $\left[{ }^{125} \mathrm{I}_{-\mathrm{Tyr}^{1}}\right]$ somatostatin 
alone. This may be due to self-polymerization and selfaggregation, and therefore, to a change of its physicochemical character (20).

Finally, the present data do not allow any conclusions about the regulatory effects of the binding factor in respect to the local functions between the different cells of the pancreatic islets. Although a specific protein binding assay for somatostatin could be developed using the pancreatic binding factor (29), described here, further work is necessary to elucidate details of the specific binding of somatostatin, to classify whether

\section{References}

1. Brazeau, P., Vale, W., Burgus, R., Ling, N., Butcher, M., Rivier, J. \& Guillemin, R. (1973), Science 179, 77-79.

2. Elde, R., Hökfeld, T., Johansson, O., Schutzberg, M., Efendic, S. \& Luft, R. (1978), Metabolism 27, Suppl 1, $1151-1159$

3. Dubois, P. M., Paulin, C. \& Dubois, M. P. (1976), Cell Tiss. Res. 166, 179-184.

4. Orci, L., Baetens, D., Dubois, M. P. \& Rufener, C. (1975), Horm. Metab. Res. 7, 400-402.

5. Arimura, A., Sato, H., Dupont, A., Nishi, N. \& Schally, A. V. (1975), Science 189, 1007-1009.

6. Krejs, G. J., Orci, L., Conlon, J. M., Ravazzola, M., Davis, G. R., Raskin, P., Collins, S. M., McCarthy, D. M., Baetens, D., Rubenstein, A., Aldor, T. A. M. \& Unger, R. H. (1979), N. Engl. J. Med. 301, 285-292.

7. Brown, M. \& Vale, W. (1978), Biomedicine 28, 93-96.

8. Ogawa, N., Thompson, T., Friesen, H. G., Martin, J. B: \& Brazeau, P. (1977), Biochem. J. 165, 260-277.

9. Alberti, K. G. M. M., Christensen, N. J., Enkjaer Christensen, S., Prange Hansen, A., Iversen, J., Lundbaek, K., SeyerHansen, K. \& Ørskow, H. (1973), Lancet II, 1299-1301.

10. Zühlke, H., Ziegler, M., Jahr, H., Titze, R. \& Schmidt, S. (1978), Acta Biol. Med. Germ. 37, K15-K18.

11. Weir, G. C., Goltos, P. C., Steinberg, E. P. \& Patel, Y. C. (1976), Diabetologia 12, 129-132.

12. Marchalonis, J. (1969), Biochem. J. 113, 299-305.

13. Diel, F., Schneider, E. \& Quabbe, H.-J. (1977), J. Clin. Chem. Clin. Biochem 15, 669-677.

14. Bradford, M. M. (1976), Anal. Biochem. 72, 248-254.

15. Davis, B. J. (1976) in: Disc Electrophoresis (Distillation Prod. Div. Eastman Kodak Co., Ed.) Rochester, N. Y

16. Helenius, A. \& Simons, K. (1972), J. Biol. Chem. 247, $3656-3661$. the binding factor acts as a carrier protein, and whether specific receptors are located at the islet cells of the pancreas.

\section{Acknowledgements}

The authors whish to thank Mrs. Margrit Rösick for her expert assistance. We are grateful to Dr. H. Pickartz and Dr. G. Jautzke, Institute of Pathology, Klinikum Steglitz, Free University Berlin, for electronmicroscopy and immunoperoxidase staining.

This work was supported by the Deutsche Forschungsgemeinschaft (Di 239/1).
17. Diel, F. \& Bethge, N. (1979), Kolloquium Analytische Chemie, Duisburg, Abstr. 3.

18. Schonbrunn, A. \& Tashjian, A. H. (1978), J. Biol. Chem. 253, 6473-6483.

19. Vale, W., Brazeau, P., Rivier, C., Brown, M., Boss, B., Rivier, J., Burgus, R., Ling, N. \& Guillemin, R. (1975), Rec. Progr. Horm. Res. 31, 365-397.

20. Diel, F., Schneider, E. \& Baumann, H. (1977) IAEA-SM 220, 123-132.

21. Millar, R. P. (1978), J. Endocrinol. 77, 429-430.

22. Spiess, J. \& Vale, W. (1978), Metabolism 27, Suppl. 1, $1175-1178$.

23. Harris, V., Conlon, J. M., Srikant, C. B., McCorkle, K., Schusdziarra, V., Ipp, E. \& Unger, R. H. (1978), Clin. Chem. Acta 87, 275-283.

24. Kronheim, S., Berelowvitz, M. \& Pimstone, B. L. (1978), Diabetes 27, 523-529.

25. Conlon, J. M., Srikant, C. B., Ipp, E., Schusdziarra, V., Vale, W. \& Unger, R. H. (1978), J. Clin. Invest. 12, 1187-1193.

26. Ogawa, N., Thompson, T. \& Friesen, H. G. (1978), Can. J. Phy siol. Pharmacol. 56, 48-53.

27. Arimura, A., Sato, H., Coy, D. H. \& Schally, A. V. (1975b), Proc. Soc. Exp. Biol Med. 148, 784-789.

28. Leitner, J. W., Ritkin, R. M., Maman, A. \& Sussman, K. E. (1979), Biochem. Biophys. Res. Comm. 87, 919-927.

29. Bethge, N., Diel, F., Rösick, M., Holz, J., Thomsen, P. D. \& Quabbe, H.-J. (1980), Abstracts Joint Meeting Hamburg, J. Clin. Chem. Clin. Biochem. 18, 734.
Dr. F. Diel

Abt. Arbeitsmedizin. Toxikologie Institut für Arbeitsphysiologie an der Universität Dortmund Ardeystraße 67 D-4600 Dortmund 1 